\title{
RETHINKING TERRORISM FINANCING AND \\ DEMOCRACY IN AFRICA: THE NIGERIA CASE
}

\section{Friday E. Nkwede*, Joseph O. Nkwede* \& Bigben C. Ogbonna* http://dx.doi.org/10.4314/og.v16i1.9}

\begin{abstract}
Terrorism financing has become a threat to humanity and democracy in Africa. Most terrorist organizations in Africa need money to carry out their massacre activities, which threatens African democracy, political stability, and economic development. The wave of terrorism activities and terrorism financing in Africa have remained a major cause for concern. The pervasive widespread of terrorist attacks seem to have defile all situations. Apparently, in Nigeria, terrorist attack reports have become a daily menu. The lethal killings by Boko Haram in Nigeria can be likened to the era of the Nigerian Civil war. This paper therefore, compares and contrasts the terrorism financing vis-à-vis the nascent democracy in Africa with a focus on Nigerian cases of Boko Haram. Terrorism financing misrepresents democratic growth and economic development in Africa, which brought about a rise in terrorist widespread and negative financial growth and progress in Nigeria and Africa. The multi-dimensional of terrorist financing has brought difficulties to trace terrorist funds due to legitimize illegal sourcing of funds to terrorist accounts. The paper finds that the current wave of terrorism financing have made African democracy unstable and pathetically feeble.
\end{abstract}

Keywords: Terrorism, financing, security, democracy

\section{Introduction}

Currently, terrorism is no longer a word, it is a weapon. In the same way, the expression-'terrorism financing' has become a bludgeon and not a phrase. As a substance of verity, the wave of terrorism activities and terrorism financing in Africa have remained a major security threat to humanity and democratic devotion. The pervasive widespread of terrorist attacks seem to have defile all situations. Apparently, in Nigeria, terrorist attack reports have become a daily menu. The lethal killings by Boko Haram in Nigeria, in particular, can be likened to the era of the Nigerian Civil war. The alliance of 
Boko Haram with AQIM has made West Africa the operational base of all terrorism activities with Nigeria as their regional headquarters. Boko Haram alliance houses other international terrorist groups such as the movement for Oneness and Jihad in West Africa (MUJAO), the national movement for the liberation of Azawad (NMLA) and the AnsarEddine in Mali and Niger.

Evidently, Boko Haram alliance in the form AQIM has continued to strategically provide financing for training and other logistical support to terrorist groups in Nigeria and another part of African countries. The activities of the terrorist group in Nigeria have made the nascent democracy in Africa very fragile. To say that the effect of terrorist activities and terrorist financing are devastating, alarming, distressing, shocking and demoralizing is to say the least. As matter of fact, and for the purpose of protecting the nascent democracy in Africa (and Nigeria inclusive), the effects of terrorism financing have provoked strong political interest among the authorities and National governments of Economic Community of West African State (ECOWAS) on the glaring threats and the interrogation of the modus operandi of terrorism financing. According to Financial Action Tax Force (FATF) report of 2013, the magnitude of terrorism activities and financing in Africa threatens African democracy, political stability, and economic development in many dimensions.

Additionally, the African security and democracy are highly vulnerable to terrorist financing threats in many respects. First, the African security and surveillance borders (most especially Nigeria) are very weak. This is evident by uncountable African unofficial border cross points which pave ways for massive infiltration of terrorist including all kinds of small arms and light weapons (SALW). To this effect, it has been severally reported that Boko Haram terrorist has weapons that are more sophisticated than the weapons of the Nigerian army even when the Nigerian army has the full backing of the government (Simser, 2008).

Second, terrorist groups and terrorist supporters take undo chances of the large informal and cash-based economy in most African countries to move money for the purpose of funding and financing their ill activities. The nature of the cash-based economy, particularly in Nigeria has made cash carrying and cash-based 
Nkwede et al: rethinking terrorism financing and democracy ...

transaction get ways for the terrorist to move cash freely and easy conversion of their materials to cash. The cash helps the terrorist in all their logistics supports and other cash transactions. The danger associated with the cash-based economy has necessitated the Nigerian Central Bank policy which has increased the electronic banking system in Nigeria. The advantage of the cashless economy in respect to terrorist financing is that terrorist money cell can be traced, trapped and stopped by the financing institutions and other financing intelligent organs of international communities (Walker, 1998).

Third, international collaborations and domestic inter-agency co-operation remain weak. The light of this weakness is in the area of information sharing especially among the ECOWAS member states in Africa. No doubt, this challenge provides an atmosphere for the illicit flow of cash as well as small arms and light weapons across the border undetected. This again gives way for a terrorist to strongly equip their camp and carry out any operation at my point in time.

Fourthly, another area where African democracy and human security are threatened is the reporting standard. According to FATF (2013), most reporting institutions in Nigeria and other African countries often do not have the full capacity to identify suspicious transactions related to terrorist financing. This is becoming worst when a banker in Kenya cannot identify that the terrorist call he/she is looking at in Kenya banking system moving to Afghanistan is a terrorist funds-cell made for terrorism funds. It is against this background that this chapter is motivated to juxtapose terrorism financing threats and the fragile democracy in Africa. Another section of the chapter is arranged as follows: Section two dwells on the Literature which focuses mainly on the conceptual clarification, Section three considers the financing typology, with its effect on democratic development in Africa. Section four considers the link between terrorism and money laundering, while section five concludes the study. 


\section{Conceptual Delineation}

\section{The concept of terrorism and terrorism financing}

The concept of terrorism has a watershed definition. As such, the director of the Institute of War and Peace studies, Colombia University argues that terrorism as a concept has suffered semantic bedlam over the year. According to him, there have never been any consensus definitions of terrorism. In collaboration, Steve and Nocella (2002) followed the interrogation approach in addressing the concept of terrorism in Africa. The interrogations on the concept have helped to shade light to the concept of terrorism and make the meaning clear due to its diverse nature.

Basically, the political relativity of the concept of terrorism no doubt is shown in the trite but true maxim that "one man's terrorist is another man's freedom fighter". The United States of Africa from the state-sponsored point of view defines terrorism to include the actions of insurgency movements-social justice movements always demanded as the community in the past but never the horrors perpetuated". The position of the African definition of the concept of terrorism always deploys Manichean Good Verse Evil dramas. The precise conceptualization of terrorism according to Stephen and Anthony (2004) is summarized in this paper as follows:

Terrorism is the intentional use of physical violence directed against persons- human and $\backslash$ or nonhuman animals- to advance the religions, ideological, political, or economic purposes of an individual, organization, corporation, or state government (Ressa, 2003). Terrorism is the deliberate use of violence against in order to attain political, ideological, or religions aims (Ganor, 2004; Executive Director of the Institute for Counter-Terrorism). Terrorism is the threat and use of both psychological and physical force in violation of international law by state and sub-state agencies and political goals (Yonah, 2009). Terrorism is the premeditated, deliberate, systematic murder, maybe, and threatening of the innocent to create fear and intimidation in order to gain a political or tactical advantage to influence an audience (James, 2012). Terrorism is the systematic use of coercive intimidation against civilians for political goals... the goals of terrorism are always political... Terrorism as a political act is a primary means of expression and the 
Nkwede et al: rethinking terrorism financing and democracy ...

last resort... the targets of terrorist coexist are the civilian population (Steven and Anthony, 2004).

On the other hand, terrorism financing in its simplest clarity is summarized in this paper as the 'act of financing of terrorist and of the terrorist organization' (Financial Action Task Force, 2015). Additionally, Ehrenfeld (2005) argues that terrorism financing refers to "processing of funds to sponsor or facilitate terrorist activity." Most of the attempts in the conceptualization of terrorism financing are deeply connected to the terrorism, hence the summarized form.

\section{Typology and Source of Terrorism Financing}

There are many sources of terror financing as well as their various types. These diverse sources arise because of the terrorist diverse need for money to meet their funding requirement in different ways. The financial need of the terrorist groups greatly depends upon the purpose of the group in including their capacity, capabilities, and opportunities (Tofangsaz, 2015).

By typology, terrorist funds can be secured illegally and legally. The illegal sources of financing terrorist group are embedded in heinous criminal activities namely- arm robbery, arms trafficking, extortion, credit card frauds, smuggling, cheque fraud, racketeering, kidnap-for-ransom, drug trafficking, and narcotics. Among the entire criminal and the illegal activities highlighted above, drug trafficking is the most viable sources of funds for the most terrorist group in the world. It is the most lucrative and attractive sources; often common for the entire terrorist group for raising funds.

The second commonest source in this typology is the narcotics, referred here as "Narco-terrorism". Narcoterrorism according to Vittori (2011) is a phenomenon that involves terrorist groups cultivating, refining and distribution of narcotics across the world. It has been a trend among the terrorist group since the 1990s in other countries of the world. Example of terrorist groups that find delight infrequent source of fund via narcotic are the Revolutionary Armed Forces of Colombia, the Peruvian Shining Path, the Taliban, Al-Qaida, Islamic Movement of Uzbekistan and Boko Haram of Nigeria. As such, in 2007, it was reported by the United Nations that the total value of exported drugs used for terrorism funding stood at 
USD 4 billion among terrorist groups warlord and trafficker (Vittori, 2011).

Furthermore, the legal sources of finance to the terrorist group are free will donations, begging, business investments, the fund from donor agencies, and non- government organization (NGO's) and self - financing methods. Apparently, a nongovernment organization (NGO's) has become the channel through terrorist funds are moved to the destination countries of the world. The NGO 's are most often regarded as the faith-based organization with a religious inclination, as a matter of fact, when their bank is used to move fund, some financial institutions do not query their transactions and identities based on the already established trust of the NGO's. It is the easiest way of raising funds for terrorist groups. Business investment by terrorist comes in the form local business and small income generation. Terrorist investment in the business is in the form of investment in stock, bonds- shares, construction companies, trade business, brokers and restaurants. It is reported that terrorist invest in diverse ways for the purpose of financing terrorist activities and the maintenance of their infrastructures. For instance, Al-Qaeda boasts of several financial legitimate investments such as:

1. Investment and inheritances of Osama Bin Laden;

2. Funding from wealthy Arab supporters;

3. Contributions through charities;

4. Income from investments in legal business;

5. Criminal activities (Koh,2006). See appendix.

Importantly, it is worthy to note that apart from legal and illegal classification or typology of terrorism financing, it can also be classified into state sponsorship and politically exposed persons (PEP) sponsorship.

\section{The Synoptic Comparative View of Terrorist Attacks}

This synoptic comparative analysis is made with respect to 2014 as the base year and upon the fact that 2014 recorded the highest number of terrorist attacks and killings in Nigeria. Again the emphasis is also made to Boko Haram because it is the leading terrorist group in Nigeria and the deadliest terrorist group in the 
Nkwede et al: rethinking terrorism financing and democracy ...

world. The group according to Financial Action Taskforce Report of 2015 had conducted over 453 attacks in Nigeria, killing over 6644 people and has injured a total of 1,742 people in Nigeria alone. Their killings and attacks in Nigeria officially commenced in 2009 when their leader Yusuf Mohammed declared violence campaign in Nigeria. This was followedby the Jihad declaration of the second leader Abubaka Shekau against Nigeria and US. Since then, it has been a serious lethal killing by Boko Haram in Nigeria. Comparatively, see the table below. Again, it shows that from January $3^{\text {rd }}$ to the 2015, Boko Haram has killed 2000 persons in Baga town alone in the Borno State of Nigeria.

Table1: Twenty Most Fatal Terrorist Attacks in 2014

\begin{tabular}{|c|c|c|c|c|c|}
\hline Date & Country & City & $\begin{array}{l}\text { Fatalities } \\
\text { /injuries }\end{array}$ & Group & Description \\
\hline $10 / 06 / 14$ & Iraq & Badush & $670 / 0$ & ISIL & $\begin{array}{l}\text { Assailants stormed a prison, } \\
\text { released the Sunni inmates } \\
\text { and killed } 670 \text { Shiite } \\
\text { prisoners }\end{array}$ \\
\hline $03 / 08 / 14$ & Iraq & Sinja & $500 /-$ & ISIL & $\begin{array}{l}\text { Assailants attacked Yizidi } \\
\text { civilians in Sinjar town. At } \\
\text { least } 500 \text { people were killed } \\
\text { and } 300 \text { women were } \\
\text { kidnapped in the incident }\end{array}$ \\
\hline $05 / 05 / 14$ & Nigeria & $\begin{array}{l}\text { Gambor } \\
\text { u Ngala }\end{array}$ & $315 /-$ & Boko Haram & $\begin{array}{l}\text { Assailants attacked residents } \\
\text { and buildings with firearms } \\
\text { and explosive devices in } \\
\text { Gomboru Ngala town. At } \\
\text { least } 315 \text { people were } \\
\text { destroyed in the attack }\end{array}$ \\
\hline $17 / 07 / 14$ & Syria & $\begin{array}{l}\text { Palmyra } \\
\text { district }\end{array}$ & $310 /-$ & ISIL & $\begin{array}{l}\text { Assailants attacked National } \\
\text { Defense Force soldiers and } \\
\text { then the Shaer Gas field in } \\
\text { Homs governorate. In } \\
\text { addition to } 40 \text { assailants, } \\
270 \text { people were killed. An } \\
\text { unknown number were } \\
\text { taken hostage during the } \\
\text { attack. }\end{array}$ \\
\hline $17 / 07 / 14$ & Ukraine & Hrabove & $298 /-$ & $\begin{array}{l}\text { Donetsk } \\
\text { People's } \\
\text { Republic }\end{array}$ & $\begin{array}{l}\text { Assailants launched a } \\
\text { surface-to-air missile at a } \\
\text { Malaysia Airlines aircraft, } \\
\text { traveling from Amsterdam } \\
\text { city to Kuala Lumpur city, } \\
\text { near Hrabove village. } 298\end{array}$ \\
\hline
\end{tabular}


Ogirisi: a new journal of African studies vol.16 2020

\begin{tabular}{|c|c|c|c|c|c|}
\hline & & & & & $\begin{array}{l}\text { people were killed. The } \\
\text { Donetsk People's Republic } \\
\text { claimed responsibility for } \\
\text { the incident. }\end{array}$ \\
\hline $15 / 04 / 14$ & $\begin{array}{l}\text { South } \\
\text { Sudan }\end{array}$ & Bentiu & $287 /-$ & $\begin{array}{l}\text { Sudan } \\
\text { People's } \\
\text { Liberation } \\
\text { Movement in } \\
\text { Opposition } \\
\text { (SPLM-IO) }\end{array}$ & $\begin{array}{l}\text { Assailants attacked a } \\
\text { mosque being used as a } \\
\text { civilian shelter and abducted } \\
\text { a number of people in } \\
\text { Bentiu town. This was one } \\
\text { of five attacks in Bentiu } \\
\text { town on this day. }\end{array}$ \\
\hline $14 / 03 / 14$ & Nigeria & $\begin{array}{l}\text { Maidugu } \\
\text { ri }\end{array}$ & $212 /-$ & Boko Haram & $\begin{array}{l}\text { Assailants attacked the } \\
\text { Giwa Army Barracks a } \\
\text { University of Maiduguri } \\
\text { hostel in Maiduguri city. An } \\
\text { unknown number of } \\
\text { prisoners, who were being } \\
\text { held at the base, were freed } \\
\text { as a result of the attack. }\end{array}$ \\
\hline $17 / 09 / 14$ & Nigeria & Konduga & $201 /-$ & Boko Haram & $\begin{array}{l}\text { Assailants attacked } \\
\text { Konduga town, Borno state, } \\
\text { Nigeria. At least } 201 \\
\text { assailants were killed in the } \\
\text { attack. }\end{array}$ \\
\hline $13 / 05 / 14$ & Nigeria & $\begin{array}{l}\text { Kalabalg } \\
\text { e district }\end{array}$ & $200 /-$ & Boko Haram & $\begin{array}{l}\text { Assailants attacked residents } \\
\text { and buildings in Tsangayari } \\
\text { village. Residents repelled } \\
\text { the attack, killing } \\
\text { approximately } 200 \\
\text { assailants }\end{array}$ \\
\hline $05 / 04 / 14$ & Nigeria & $\begin{array}{l}\text { Galadim } \\
\text { a }\end{array}$ & $200 /-$ & $\begin{array}{l}\text { Fulani } \\
\text { militants }\end{array}$ & $\begin{array}{l}\text { Assailants opened fire on } \\
\text { community leaders and } \\
\text { residents that were meeting } \\
\text { in Galadima village. At least } \\
200 \text { people were killed and } \\
\text { an unknown number were } \\
\text { injured in the attack. } \\
\text { Sources attributed the attack } \\
\text { to Fulani assailants. }\end{array}$ \\
\hline $16 / 12 / 14$ & Pakistan & $\begin{array}{l}\text { Peshawa } \\
\mathrm{r}\end{array}$ & $157 / 131$ & $\begin{array}{l}\text { Tehrik- } \\
\text { Taliban } \\
\text { Pakistan } \\
\text { (TTP) }\end{array}$ & $\begin{array}{l}\text { Assailants detonated an } \\
\text { explosives-laden vehicle and } \\
\text { then stormed the Army } \\
\text { Public School in Peshawar } \\
\text { city, Khyber Pakhtunkhwa } \\
\text { province, Pakistan. At least } \\
150 \text { students and staff were } \\
\text { killed and } 131 \text { were } \\
\text { wounded in the attack. All } \\
\text { seven assailants were either } \\
\text { killed by security forces or } \\
\text { detonated their explosives- }\end{array}$ \\
\hline
\end{tabular}


Nkwede et al: rethinking terrorism financing and democracy ...

\begin{tabular}{|c|c|c|c|c|c|}
\hline & & & & & laden vests. \\
\hline $13 / 05 / 14$ & Nigeria & Garawa & $151 /-$ & Boko Haram & $\begin{array}{l}\text { Assailants attacked residents } \\
\text { and buildings in Garawa } \\
\text { village. Residents repelled } \\
\text { the attack, killing } \\
\text { approximately } 151 \\
\text { assailants. }\end{array}$ \\
\hline $16 / 12 / 14$ & Iraq & Fallujah & $150 /-$ & ISL & $\begin{array}{l}\text { Assailants killed } 150 \\
\text { women who had refused to } \\
\text { engage in a jihad marriage. }\end{array}$ \\
\hline 0709/14 & Iraq & Mosul & $150 /-$ & ISIL & $\begin{array}{l}\text { Assailants executed } 150 \\
\text { former security members in } \\
\text { Mosul city. }\end{array}$ \\
\hline $29 / 10 / 14$ & Iraq & Ramadi & $150 /-$ & ISIL & $\begin{array}{l}\text { Assailants kidnapped } 150 \\
\text { members of the Albu Nimr } \\
\text { tribe from villages near } \\
\text { Ramadi city. The victims } \\
\text { were executed and buried in } \\
\text { Albu Ali al-Jasim area. }\end{array}$ \\
\hline 28/11/14 & Nigeria & Kano & $122 / 270$ & Boko Haram & $\begin{array}{l}\text { Two suicide bombers and a } \\
\text { roadside bomb detonated at } \\
\text { the Grand Mosque in Kano } \\
\text { city. Assailants opened fire } \\
\text { on worshipers fleeing the } \\
\text { explosions. }\end{array}$ \\
\hline $17 / 12 / 14$ & Cameroon & $\begin{array}{l}\text { Am } \\
\text { Chide }\end{array}$ & $117 /-$ & Boko Haram & $\begin{array}{l}\text { Assailants attacked soldiers } \\
\text { and residents in Am Chide } \\
\text { town. The assailants } \\
\text { detonated explosives before } \\
\text { descending on Am Chide, } \\
\text { setting fire to houses and } \\
\text { shops. At least } 116 \text { attackers } \\
\text { and one soldier were killed } \\
\text { in the ensuing clash with } \\
\text { security forces. }\end{array}$ \\
\hline $15 / 02 / 14$ & Nigeria & Izghe & $106 /-$ & Boko Haram & $\begin{array}{l}\text { Assailants dressed in } \\
\text { military uniforms attacked } \\
\text { residents in Izghe village. } \\
\text { This was one of two such } \\
\text { attacks in Borno on this day. }\end{array}$ \\
\hline $06 / 09 / 14$ & Cameroon & Fotokol & $101 /-$ & Boko Haram & $\begin{array}{l}\text { Assailants attacked the } \\
\text { border town of Fotokol. }\end{array}$ \\
\hline $17 / 05 / 14$ & Nigeria & $\begin{array}{l}\text { Unknow } \\
\mathrm{n}\end{array}$ & $101 / 6$ & Boko Haram & $\begin{array}{l}\text { Assailants attempted to take } \\
\text { control of the Damaturu- } \\
\text { Benishek-Maiduguri road in } \\
\text { Borno state }\end{array}$ \\
\hline
\end{tabular}

Source: Financial Action Taskforce Report, in collaboration with Inter-Governmental Action Group Against Money Laundering in West Africa:www.fatf-gafi.org 


\section{The Consequence of Terrorism Finance Threat on Democracy in Africa}

In all democracies, especially in the continental Africa, the main objective of a terrorist group is either to preserve the status quo ante or to bring about political change. As Congleton (2002) noted, both terrorist networks and ordinary political interest groups attempt to influence controversial public policies in a manner disproportionate to their votes. The probability and extent of the success of their efforts increase as resources devoted to exerting influence expand and decline with opponent efforts to resist their aims, other things being equal. To this extent, participants are rational, institutional arrangements that change the probability of success among alternative methods of influence affect the level and allocation of group efforts across these methods. Analytically, terrorism is, simply another method that groups may use to influence decisions reached by the government. Put differently, it is another form of interestgroup politics.

Essentially, effects of terrorism on democratization are enormous and an albatross to the collective existence, peace and security in the continental Africa. This is because the menace and escapade of terrorism have to a large extent suffocated the unity, economic; imperil the peace and social emancipation in Africa. Terrorism apart from its damaging effect on the lives of citizens on a large scale has equally denied African states' stability, good governance, and sustainable development.

Another deleterious effect of terrorism is that it affects the electoral process and replacement of political leaders compared with the formulation and implication of policies that deliver public commodities. In a more amenable manner, it does not significantly influence the respect by the state and citizens in terms of institutional governance. In effect, terrorism determines voters' views and the constitution of governments in Africa and also influences the survival and effectiveness of incumbent target governments (Indridason, 2008; Williams, 2012). In other words, terrorism reduces the fair and free election in democratic centralism. This is because the mechanisms of rigging elections may probably be more apparent in a hostile environment. Ultimately, an unsecured democratic environment owing to terrorism does not offer all 
Nkwede et al: rethinking terrorism financing and democracy ...

elements of a political class the opportunity of organizing civil campaigns properly as it would be the case in an atmosphere devoid of terrorism threats.

More so, terrorism provides the incumbent government in African countries the leverage of using the heightened risk of violence with associated national unrest in maintaining their grip on power (Gilmore, 1999; Park and Bali, 2016). Similarly, in African countries, terrorism dynamics have negatively affected not only political governance and its constituents but also sparingly affected economic governance and its components.

Apparently, terrorism affects the enjoyment of human rights in a democratic society, especially in Africa. Both international and regional human rights law recognize the right and duty of states to protect those individuals subject to their jurisdiction. Counterterrorism involves deliberate or targeted killings to eliminate specific individuals as an alternative to arresting them and bringing them to justice, but, this is inimical to human existence and survival. The deprivation of life by the authorities of the African States in an attempt to fight terrorist groups is a matter of the utmost gravity.

Importantly, terrorism has become a serious threat to the democratization process in Africa. It can safely be argued that Africa is more vulnerable to terrorism. To a large extent, the problem is often compounded by centrifugalism and centripetalism coupled with the clash of civilization.

\section{Conclusion}

Terrorism financing distorts democratic survival and economic development in Africa. The financing of terrorist groups has brought about an increase in terrorist widespread in Nigeria and Africa. Negative effects of the terrorist activities have a gross effect on the democracy as a growing political ideology and process in Africa. Again, the source of terrorism finance has become multi-dimension in nature such that terrorism can be financed apparently by any means (legal and illegal). Terrorism can also be financed by anybody both intentional and unintentional. Hence, the financial flows of terrorist finance move into various directions. The proceeds of money to the terrorist cell have become difficult to trace due to some legitimization of illegal sources of funds to a terrorist cell. It is the 
Ogirisi: a new journal of African studies vol.16 2020

firm belief of this paper that terrorism financing is not only a major threat to humanity but also a threat to the nascent democracy in Africa. The threats have made African citizens and the democratic institutions unstable and pathetically feeble.

\section{*Friday E. Nkwede}

Department of Banking and Finance

Ebonyi State University, Abakaliki, Nigeria

drnkwede@gmail.com

*Joseph O. Nkwede

Department of Political Science

Ebonyi State University, Abakaliki, Nigeria

\section{*Bigben C. Ogbonna}

Department of Economics

Ebonyi State University, Abakaliki, Nigeria

bigbenogbonna@ebsu.edu.ng 
Nkwede et al: rethinking terrorism financing and democracy ...

\section{References}

Amartya, S. (2001). Democracy and Social Justice, in Farrukh. I. and Jong, I. (eds), Democracy, Market Economy and Development: An Asian Perspective, Washington D.C: World Bank.

Acharya, A. (2009). Small amounts for big bangs? Rethinking responses to "low-cost terrorism, Journal of Money Laundering and Control, 12 (3), pp. 285-298.

CNN (2011), 'Al Qaeda-linked Group Finds Fertile Territory in

Nigeria as Killings Escalate', 18 November 2011.

Defence Intelligent Agency Report, 2002.

Department of Defense, USA, 2014.

Elaigwu, J.I. (2011). Tropical Issues and Nigeria's Political Development, Jos: AHA Publishing Company.

Ehrenfeld, R. (2005). Funding Evil: How Terrorism is Financed - And How to Stop It? Bonus Books, Chicago, IL.

Ehrenfeld, R. (2007). "Funding evil": how terrorism is financed, the nexus of terrorist and criminal organizations" in Costigan, S.S. and David, G. (Eds), Terrornomics, Ashgate Publishing, England.

FATF Report (2013) on Terrorism in West Africa.

FATF Report (2015) on Terrorism in West Africa.

Gunaratna, R. and Acharya, A. (2005).“The terrorist training camps of Al Qaeda", in Forest, J.F.(Ed.), The Making of a Terrorist: Recruitment, Training, and Root Causes, Praeger, Westport, CT.

Gilmore, W.C. (1999). Dirty money: The Evaluation of money laundering counter-measures, Council of Europe Press, Strasbourg.

Gnor, M. (2004), cited in Steven,B. and Anthony, C. (2004), Animal liberation philosophy and policy journal, volume 2, NO.1 2004, pp. 1- 28.

Indridason, I.H. (2008). Does Terrorism Influence Domestic Politics? Coalition Formation and

Terrorist Incidents, Journal of Peace Research, 45(2), 241-259.

Jega, A. (2007). Democracy, Good Governance, and Development in Nigeria, Ibadan: Spectrum Books Limited. 
Ogirisi: a new journal of African studies vol.16 2020

James, G.(2012), cited in Steven,B. and Anthony, C. (2004), Animal liberation philosophy and policy journal, volume 2, NO.1 2004, pp. 1- 28.

Koh, J. (2006). Suppressing Terrorist Financing and Money Laundering, Springer, Berlin.

Nkwede, J.O. (2011). Human Rights, Democracy and Kidnapping in Eastern Nigeria: The Need for Alternative Strategies,Journal of Society, 1(1), 70-78.

Nkwede, J.O. (2013). Democracy, Terrorism and the Paradox of Insecurity Vortex in Nigeria, Global Journal of Human Social Science 13(7), 43-51.

Park, J. and Bali, V. (2016). International Terrorism and the Political Survival of Leaders, Journal of Conflict Resolution, Doi: 10.1177/0022002715613139.

Ressa, M.A. (2003). Seeds of Terror: An Eyewitness Account of AlQaeda's Newest Center of Operations in Southeast Asia, The Free Press, New York, NY.

Reeve, S. (1999). The New Jackals: Ramzi Yousef, Osama bin Laden and the Future of Terrorism, Deutsch, London.

Simser, J. (2008), "Money laundering and asset cloaking techniques", Journal of Money, Laundering Control, Vol. 11, p. 15.

Steven,B. and Anthony, C. (2004), Animal liberation philosophy and policy journal, volume 2, NO.1 2004, pp. 1- 28.

Tofangasaz, H. (2015). Rethinking terrorist financing: where does all this lead? Journal of Money Laundering and Control, 18(1), pp. $112-130$.

UN Security Council Resolution 1566 (2004).

Vittori, Jodi (2011), Terrorist Financing and Resourcing, Palgrave Macmillan, New York NY, United States.

Walker, J. (1998). Global Money Laundering Flows - Some Findings, available at www. johnwalkercrimetrendsanalysis.com.au/ML\%20method.htm (accessed 22 August 2011).

Williams, L.K. (2012). The Political Consequences of Terrorism: Terror Events, Causalities, and Government Duration, International Studies Perspectives 3(1) , 1-19. 
Nkwede et al: rethinking terrorism financing and democracy ... Appendix: Typology and Sources Terrorism Finance Source: Authors' composition

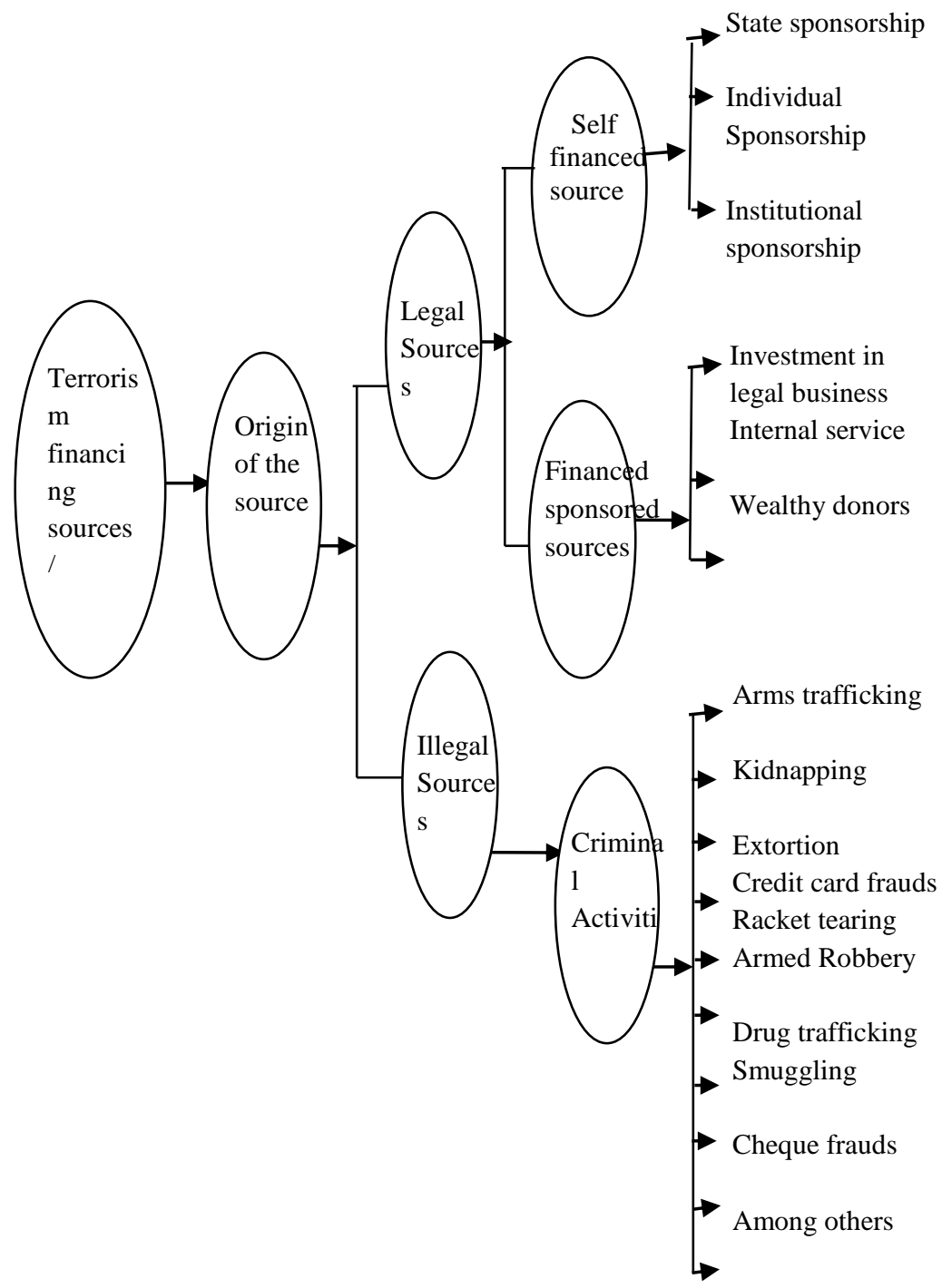

